\title{
EFFECT OF DIFFERENT FOOD TYPES ON THE BIOLOGY, FECUNDITY AND LIFE TABLE PARAMETERS OF THE STORED GRAIN MITE GOHIERIA FUSCA (OUD.) (ACARI : ASTIGMATA : LAPIDOPHORIDAE)
}

\author{
TAHA, H. A. ${ }^{1}$, HANNA I. MAHMOUD ${ }^{2}$, M. I. HASSAN ${ }^{2}$, NAHED R. OMAR ${ }^{2}$ \\ AND HEBA M. NASR ${ }^{1}$.
}

1. Plant Protection Research Institute, ARC, Dokki, Giza.

2. Fac. of science, Al-Azhar University, Nasr City, Cairo.

(Manuscript received 2 December 2009 )

\begin{abstract}
Biological studies were carried out on the stored grain mite Gohieria fusca (Oud.), where it fed on three different food sources: dry yeast granules, crushed wheat and crushed maize to determine the ability of mite Gohieria fusca to feed on, develop, fecundity, reproduction and life table parameters as a sole food sources under laboratory conditions of $25 \pm 2{ }^{\circ} \mathrm{C}$ and $65 \%$ R.H. Obtained results and statistical analysis showed that developmental stages, fecundity, reproduction and life table parameters of mite were affected by different food types, whereas, total immature stages lasted (31.22 \& 29.92), (34.73 733.38$)$ and (31.81 \& 29.78) days for female and male, when mite fed on the above mentioned diets respectively. Female oviposition period lasted 26.8, 30.9 and 29.1 days, which deposited an average numbers of eggs with a daily rate (132.9 \& 4.96), (111.5 \& 8.87) and (91.3 \& 3.14) eggs, when mite fed on dry yeast granules, crushed wheat and crushed maize respectively.
\end{abstract}

\section{INTRODUCTION}

Mites, insect and fungi infesting stored grains and other products are responsible for causing both qualitative and quantitative losses especially when stored in moist and unhygienic conditions (Sinha et al., 1962). A stored grain granaries and bulk constitutes considered a biological systems with limited energy and are influenced by several a biotic and biotic factors. Stored grains are considered one of the most important sources of human food, therefore, it is necessary to study the pests which attack them causing much harmful which leading to decrease the amount of storage grains. Astigmatid mites form an important group among biotic factors although they are very small in size cause considerable damage in stored grains when high moisture content. The amount of damage caused by stored product mites has been studied by Cunnington (1972) to be roughly proportional to the size of their population. The growth of mite population is directly related with the biological as well as physical factors operating the ecosystem Maurya and Jamil (1982), El- Naggar et al (1989) and Taha et al., (2004) had attributed the growth promoting quality to dried yeast powder. 
It is well known that stored product mites greatly differ in their behavior feeding habits, Wafa et al., (1966), Taha (1985), Saleh et al., (1987), Fawzy (1996) and Okabe and Oconor (2001), they reported that the most of mite species belonging to sub- order Astigmata attack different stored products such as wheat-grain, flour, wheat-hay, wheat-bran, rice, horse beans, lentil, dry frits, cowpea, maize, dry dates, pepper, barley, grass-seeds, cot clover, bulbs, dried milk and others. The Lapidophorid mite Gohieria fusca (Oud.) is commonly found in wheat-grain and wheat-bran in Dakahlyia Governorate. The present work aims to study the effect of different food types: dry yeast granules, crushed wheat and Crushed maize at $25 \pm 2{ }^{\circ} \mathrm{C}$ and $65 \%$ R.H.

\section{MATERIALS AND METHODS}

Gohieria fusca (Oud.) was reared under controlled laboratory condition of temperature $\left(25 \pm 2{ }^{\circ} \mathrm{C}\right)$ and relative humidity $65 \%$, where mites fed on dry yeast granules, crushed wheat and crushed maize. To make a pure culture of Gohieria fusca using plastic block $(5 \times 5 \times 1.5 \mathrm{~cm})$ each one contained a small rearing circular chamber $(1.2 \times 0.5 \mathrm{~cm})$, the bottom of each chamber was covered with mixture of plaster Paris charcoal and the top covered with small slide glass. Two adults (female and male) are sufficient to make pure culture were placed in rearing chamber and provided with food, with adding few drops of water by searching needle as source of humidity and then placed on an incubator at $25 \pm 2{ }^{\circ} \mathrm{C}$ and $65 \%$ R.H.Thirty replicates were used, each one have a single egg and then investigated twice daily, with adding a few pieces of different food types. The biological aspects, fecundity were recorded.

\section{RESULTS AND DISCUSSION}

In this study the investigation were conducted under laboratory conditions $\left(25 \pm 2{ }^{\circ} \mathrm{C}\right.$ and $65 \pm 5 \%$ R.H.) to evaluate the different biological developmental stages, fecundity, reproduction and life table parameters of the Lapidophorid mite Gohieria fusca when fed on: dry yeast granules, crushed wheat and crushed maize.

\section{Habitat and Behavior}

Numerous mite individuals of G. fusca found infesting different stored grains and its products such a maize, wheat-grain, wheat-bran, flour........etc. in different locations of Dakahlyia Governorate. Adult female and male are brown in color, while the immature stages are white.Laboratory observation showed that only copulated female laid eggs, while unmated female kept under observation until death did not oviposite any eggs. 


\section{Mating}

Mating is necessary for the mite $G$. fusca, whereas copulation between male and female were occurred immediately after the emergence of female from the last quiescent period. During copulation, the male assumed a dorsoposterior position with its legs in opposite direction with female, then the aedegus inserted into the female posterior bursa copulatrix. During this action female could move, but in slow way. The matting period lasted about 15-25 minutes.

\section{Hatching}

Eggs were laid singly in cracks and scattered cells, the deposited eggs are usually spherical and translucent, then changes to white color. During hatching the shell rupture through a longitudinal slit from which larva crawls outside with its legs leaving the egg shell. This process lasted about 20 minutes. The hatching larva stayed inactive for a short period about 5 minutes, then began its activity.

\section{Molting}

Each immature stage of G. fusca when-full grow enters in quiescent period in which it seeks a dry hole cracks in the substrate of rearing cells. The legs become shrinked and contracted under the body surface, while body color becomes pale brown, the anterior part of mite body become translucent and the old skin ruptured along transversal line behind the hysterosomal region. The hind legs appear from the old skin at first, then the new stage crawls backward to get ride of the old exuvia. Newly emerged individuals kept quite beside its old skin for a short time, then started to more actively searching for food. Molting lasted about 45 minutes.

\section{Biological aspects}

\section{Incubation period}

As shown in tables ( $1 \& 2$ ) the incubation period of the astigmatid mite $G$. fusca female and male were significantly affected by the type of different food types at 25 ${ }^{\circ} \mathrm{C}$. Female and male incubation period durated (5.0 \& 4.6), (6.8 \&6.1) and (5.5 \& 4.8) days at the same trend.

\section{Total immature stages}

Female total immature stages stayed $13.43,16.5$ and 20.8 days, while for male this period lasted $11.56,15.09$ and 18.57 days. Thus, the male total immature stages being shorter than female, therefore male becoming adult before female.

\section{The generation period}

Female generation period required 40.8. 47.7 and 42.19 days, when fed on dry yeast granules, crushed wheat and crushed maize at the same pattern. 


\section{Longevity}

Statistical analysis of the obtained results cleared that feeding on crushed wheat prolonged the longevity period of female (45.2 days) comparing with dry yeast granules (40.8 days) and crushed maize (42.3 days).

\section{The oviposition period}

From the tabulated results cleared highly difference in oviposition period of Lapidophorid mite G. fusca, whereas, feeding on dry yeast granules shortened this period (26.8 days) and longed (30.9 days) on crushed wheat, while it was intermediate on crushed maize.

\section{Fecundity}

Female fecundity of astigmatid mite $G$. fusca was affected by the different food types, thus, female fecundity decreased from 132.9 eggs on dry yeast granules to 111.5 eggs on crushed wheat and to 91.3 eggs on crushed maize, with a daily rate of 4.96, 3.6 and 3.14 eggs respectively. These results coincided with those obtained by El- Naggar et al., (1989) and Taha et al., (2004).

\section{Reproduction and feeding}

Three virgin females of G. fusca, with three newly emerged males were kept in glass container ( $5 \mathrm{~cm}$ in diameter) under the same laboratory conditions, whereas, each was provided with dry yeast granules, crushed wheat and crushed maize, after four weeks immixtures and adults were counted. Three replications for each types of food of their experiment were carried out.Female reproduction were individuals 428 (rang 375 - 495), 312 individuals (rang 252 - 336) and 242 individuals (rang $220-$ 294). Reproduction was fond to be greatly the type of the applied diet. In this respect, feeding on dry yeast granules recorded high reproduction rates, while the least was recorded on crushed maize, however, feeding on crushed wheat supported moderate reproduction.

\section{Life table parameters}

The effect of different food types (dry yeast granules, crushed wheat and crushed maize) on the life table parameters of astigmatid mite $G$. fusca when reared under laboratory conditions of $25{ }^{\circ} \mathrm{C}$ and $65 \%$ R.H.was shown in table (4). Obtained data revealed that the net reproduction rate $\left(R_{0}\right)$ which is a product of mean total fecundity. The net reproduction rate $\left(R_{0}\right)$ which is a survival rate showed $71.98,73.55$ and 58.08. Expected (female / per female ) when mites fed on the previously mentioned diets, while the mean generation time $(T)$ was 43.31 , 48.59 and 44.89 at the same trend, while the intrinsic rate of increase $\left(r_{m}\right)$ were $0.26,0.23$ and 0.24 when individuals were raised on the same diets. The finite rate of increase $\left(\exp _{\mathrm{rm}}\right)$ 
were $1.29,1.26$ and 1.28 when mites fed on previously diets. Obtained data revealed that survival rate sex ratio of progeny (female / total) were $0.72,0.65$ and 0.62 as the same pattern.

Table 1. Duration of different stages of Gohieria fusca female when fed on different food sources at $25+2^{\circ} \mathrm{C}$ and $65+5 \%$ R.H.

\begin{tabular}{|c|c|c|c|c|c|}
\hline \multicolumn{2}{|l|}{ Stage } & Dry yeast & Crushed wheat & Crushed maize & L.S.D. \\
\hline \multicolumn{2}{|l|}{ Incubation period } & $5.17 \pm 0.55^{b}$ & $6.77 \pm 0.43^{a}$ & $5.48 \pm 0.49^{b}$ & 0.34 \\
\hline \multirow{2}{*}{ Larva } & $\mathrm{A}$ & $7.39 \pm 0.55^{\mathrm{b}}$ & $8.73+0.46^{a}$ & $7.43+0.58^{b}$ & 0.43 \\
\hline & $\mathrm{Q}$ & $7.22+0.38^{a}$ & $2.36+0.49^{a}$ & $2.29+0.45^{a}$ & 0.36 \\
\hline \multirow{2}{*}{ Protonymph } & $\mathrm{A}$ & $8.22 \pm 0.49^{a}$ & $9.05+0.38^{\mathrm{a}}$ & $8.38 \pm 0.49^{b}$ & 0.36 \\
\hline & Q & $2.17 \pm 0.35^{\mathrm{a}}$ & $2.41 \pm 0.50^{\mathrm{a}}$ & $2.33 \pm 0.47^{a}$ & 0.36 \\
\hline \multirow{2}{*}{ Tritonymph } & $A$ & $8.44 \pm 0.46^{b}$ & $9.32 \pm 0.48^{a}$ & $8.52 \pm 0.49^{b}$ & 0.38 \\
\hline & $\mathrm{Q}$ & $2.83 \pm 0.38^{\mathrm{a}}$ & $2.91 \pm 0.29^{a}$ & $2.86 \pm 0.35^{a}$ & 0.26 \\
\hline \multicolumn{2}{|l|}{ Total immature } & $31.22+0.85^{\mathrm{b}}$ & $34.73 \pm 0.94^{a}$ & $31.81 \pm 1.26^{b}$ & 0.82 \\
\hline \multicolumn{2}{|l|}{ Life cycle } & $36.39+0.98^{c}$ & $41.41 \pm 0.79^{a}$ & $37.29 \pm 1.45^{\mathrm{b}}$ & 0.89 \\
\hline \multicolumn{2}{|l|}{ Generation period } & $40.80 \pm 1.16^{\mathrm{b}}$ & $47.7 \pm 1.07^{a}$ & $42.19 \pm 1.32^{b}$ & 1.47 \\
\hline \multicolumn{2}{|l|}{ Longevity } & $37.80 \pm 5.2^{b}$ & $45.20 \pm 2.69^{a}$ & $42.30 \pm 1.25^{\mathrm{a}}$ & 4.29 \\
\hline \multicolumn{2}{|l|}{ Life s[pan } & $74.0 \pm 4.85^{c}$ & $86.40 \pm 2.84^{a}$ & $79.20+1.93^{b}$ & 4.25 \\
\hline
\end{tabular}

- $\quad \mathrm{A}=$ Active stage

- $Q=$ Quiescent stage

- $\quad$ L.S.D. = Least significant differences at 0.05

Table 2. Duration of different stages of Gohieria fusca male when fed on different food sources at $25+2{ }^{\circ} \mathrm{C}$ and $65+5 \%$ R.H.

\begin{tabular}{|c|c|c|c|c|c|}
\hline \multicolumn{2}{|c|}{ Stage } & Dry yeast & $\begin{array}{r}\text { Crushed } \\
\text { wheat }\end{array}$ & $\begin{array}{r}\text { Crushed } \\
\text { maize }\end{array}$ & L.S.D. \\
\hline \multicolumn{2}{|c|}{ Incubation period } & $4.58 \pm 0.51^{\mathrm{b}}$ & $6.13 \pm 0.28^{\mathrm{a}}$ & $4.78+0.49^{b}$ & 0.45 \\
\hline \multirow[t]{2}{*}{ Larva } & A & $7.17 \pm 0.39^{b}$ & $8.13 \pm 0.28^{\mathrm{a}}$ & $7.11 \pm 0.51^{\mathrm{a}}$ & 0.45 \\
\hline & Q & $2.17 \pm 0.39 a$ & $2.25 \pm 0.37^{\mathrm{a}}$ & $2.00 \pm 0.00^{\mathrm{a}}$ & 0.35 \\
\hline \multirow[t]{2}{*}{ Protonymph } & A & $7.83+0.39 \mathrm{~b}$ & $9.0 \pm 0.00^{\mathrm{a}}$ & $7.89 \pm 0.51^{b}$ & 0.51 \\
\hline & $\mathrm{Q}$ & $1.92 \pm 0.29 a$ & $2.00 \pm 0.00^{\mathrm{a}}$ & $2.00 \pm 0.00^{\mathrm{a}}$ & 0.19 \\
\hline \multirow[t]{2}{*}{ Tritonymph } & A & $8.42 \pm 0.51 b$ & $9.38 \pm 0.41^{a}$ & $8.33 \pm 0.43^{b}$ & 0.51 \\
\hline & $\mathrm{Q}$ & $2.42 \pm 0.51 a$ & $2.63+0.41^{a}$ & $2.44 \pm 0.45^{\mathrm{a}}$ & 0.51 \\
\hline \multicolumn{2}{|c|}{ Total immature } & $29.92 \pm 1.08 \mathrm{~b}$ & $33.38+1.04^{\mathrm{a}}$ & $29.78 \pm 1.11^{\mathrm{b}}$ & 1.20 \\
\hline \multicolumn{2}{|c|}{ Life cycle } & $34.4 \pm 1.24 \mathrm{~b}$ & $39.50 \pm 1.04^{\mathrm{a}}$ & $34.56 \pm 1.14^{\mathrm{b}}$ & 1.28 \\
\hline \multicolumn{2}{|c|}{ Longevity } & $37.30 \pm 3.74 b$ & $44.60 \pm 2.91^{\mathrm{a}}$ & $40.20 \pm 2.15^{b}$ & 3.73 \\
\hline \multicolumn{2}{|c|}{ Life $s[$ pan } & $71.67 \pm 5.47 \mathrm{~b}$ & $84.17 \pm 3.87^{a}$ & $75.17 \pm 2.86^{\mathrm{b}}$ & 7.15 \\
\hline
\end{tabular}

- $\mathrm{A}=$ Active stage

- $Q=$ Quiescent stage

- $\quad$ L.S.D. = Least significant differences at 0.05 
Table 3. Adult female longevity and fecundity of Gohieria fusca when fed on different food sources at $25+2{ }^{\circ} \mathrm{C}$ and $65+5 \%$ R.H.

\begin{tabular}{|c|c|c|c|c|c|c|c|}
\hline \multirow{2}{*}{ Diet } & \multicolumn{3}{|c|}{ Average duration (days) } & \multirow{2}{*}{ Longevity } & \multicolumn{2}{|c|}{ Fecundity } & \multirow{2}{*}{ Sez ratio } \\
\cline { 2 - 3 } & Preoviposion & Oviposition & Postoviposition & (days0 & Eggs/female & daily & (\%females/total) \\
rate & \\
\hline Dry & $4.50 \pm 0.53^{\mathrm{a}}$ & $26.8 \pm 4.47^{\mathrm{b}}$ & $7.50 \pm 2.01^{\mathrm{a}}$ & $38.8 \pm 5.20^{\mathrm{b}}$ & $132.90 \pm 17.03^{\mathrm{a}}$ & 4.96 & $72 \%$ \\
\hline yeast & & & & & & & \\
\hline $\begin{array}{c}\text { Crushed } \\
\text { wheat }\end{array}$ & $5.20 \pm 0.63^{\mathrm{a}}$ & $30.90 \pm 2.18^{\mathrm{a}}$ & $9.10 \pm 1.19^{\mathrm{a}}$ & $45.20 \pm 2.69^{\mathrm{a}}$ & $111.50 \pm 8.87^{\mathrm{b}}$ & 3.60 & $65 \%$ \\
\hline $\begin{array}{c}\text { Crushed } \\
\text { maize }\end{array}$ & $4.90 \pm 0.74^{\mathrm{a}}$ & $29.10 \pm 1.37^{\mathrm{a}}$ & $8.30 \pm 0.67^{\mathrm{a}}$ & $42.30 \pm 1.25^{\mathrm{a}}$ & $91.30 \pm 8.33^{\mathrm{c}}$ & 3.14 & $62 \%$ \\
\hline L.S.D. & 0.79 & 3.69 & 1.74 & 4.29 & 12.76 & - & \\
\hline
\end{tabular}

- L.S.D. = Least significant differences at 0.05

Table 4. Effect of different food sources on life table parameters of Gohieria fusca at $25+2{ }^{\circ} \mathrm{C}$ and $65+5 \%$ R.H.

\begin{tabular}{|c|c|c|c|}
\hline Parameters & Dry yeast & Crushed wheat & Crushed maize \\
\hline Net reproduction rate (RO) & 71.98 & 73.55 & 58.86 \\
\hline Mean generation time (T) & 43.31 & 48.59 & 44.89 \\
\hline Intrinsic rate of increase (rm) & 0.26 & 0.23 & 0.24 \\
\hline Finite rate of increase (expm) & 1.29 & 1.26 & 1.28 \\
\hline Sea ratio (\% female/total) & 0.72 & 0.65 & 0.62 \\
\hline
\end{tabular}


Fig. (1) : Duration of different stages of Gohieria fusca females when fed on different food sources at $25^{\circ} \mathrm{C}$ and $65 \%$ R.H.
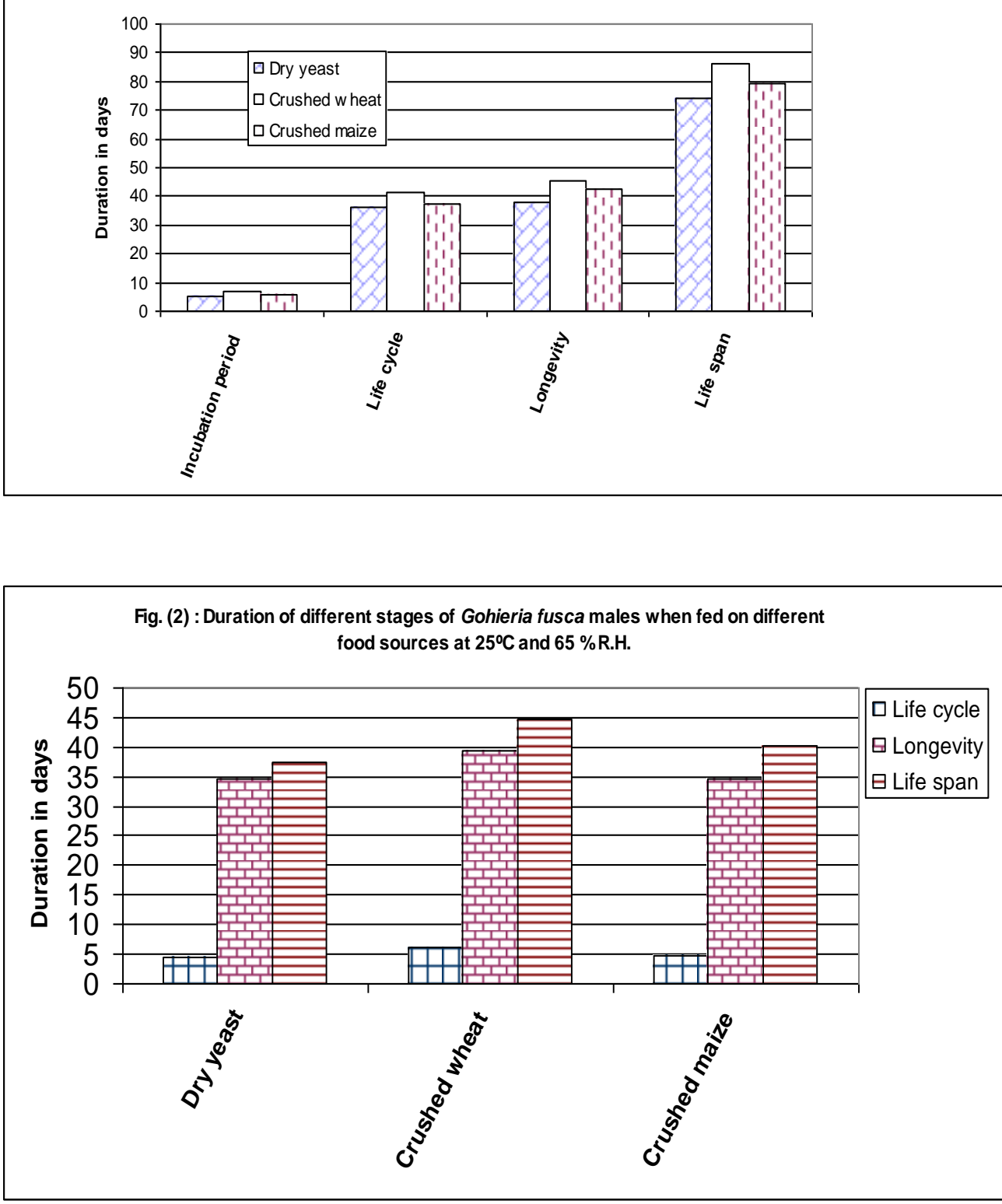

PARAMETERS OF THE STORED GRAIN MITE GOHIERIA FUSCA (OUD.)

(ACARI : ASTIGMATA : LAPIDOPHORIDAE)

Fig. (3) : Adult female longevity of Gohieria fusca when fed on different food sources at $25 \mathrm{C}$ and $65 \%$ R.H.
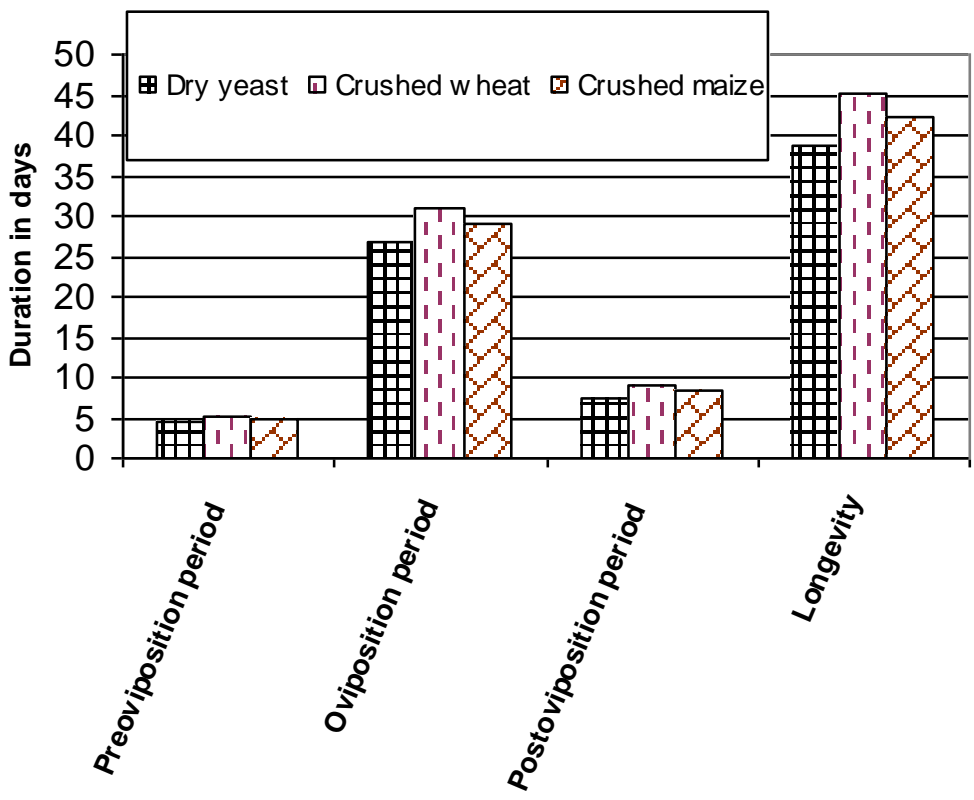

Fig. (4) : Effect of different food sources on Gohieria fusca female fecundity produced at $25 \mathrm{C}$ and $65 \%$. R. H.

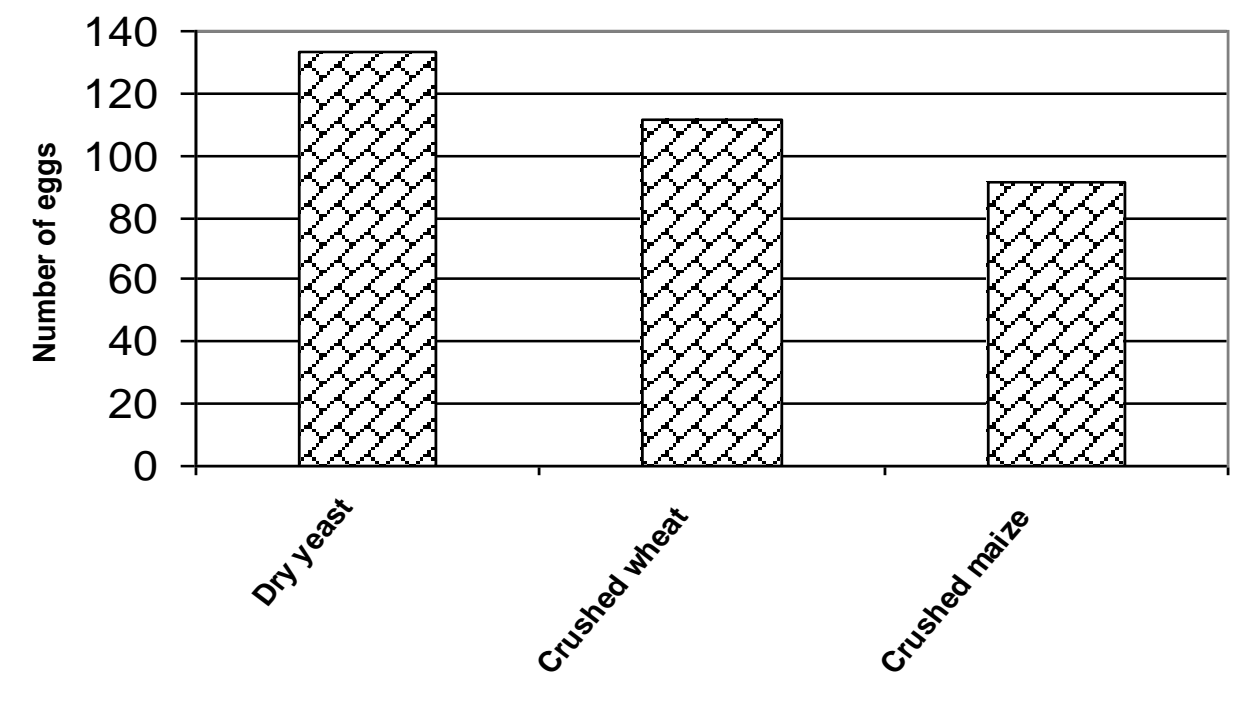




\section{REFERENCES}

1. Cunnington, A. M. 1976. Studies on some stored product mites. Ann. Appl. Biol. $82: 175-178$.

2. El- Naggar, M. E., H. A. Taha and F. M. Hoda. 1989. Biological studies on Rhizoglyphus ismaili (Astigmata : Acaridae) and the effect of types food on duration and fecundity. Bull. Zool. Soc. Egypt (38): $81-86$.

3. Fawzy, M. M. 1996. Studies on house dust mites in Egypt. Ph.D. Thesis, Fac. of Agric., Cairo Univ. 257 PP.

4. Maurya, K. R. and Z. Jamil. 1982. Survey on storage Acari in luck now India Bid. Mem., 6(2) : $97-122$.

5. Okabe, K. and B. N. Oconor. 2001. A method for both mass and individual rearing of fungivours astigmatid mites (Acari: Exp. 8 apple. Acarol., 25 : 493 - 504.

6. Saleh, S. M. , Yacout and M. M. Sadek. 1987. Biological changes in sound dry dates associated with mite infestation. Alex. J. Agric. Research. 32(1): 477 - 489.

7. Sinha, R.N., Liscombe and H. A. H. Wallance. 1962. Association of granary mites and seed borne fungi in stored grain Can. Entomol. 94(5) : 542 - 555.

8. Taha, H. A. 1985. Morphological and Biological studies on some mites associated with stored products. Ph.D. Thesis, Fac. of Agric. Al- Azhar Univ. 164 PP.

9. Taha, H. A. , K. S. Abou-El-Ela and M. A. El-Sanady. 2004. Effect of food and temperature on developmental stages and fecundity of the grain mite Dermatophagoides farinae Hughes (Acari : Acaridida : Pyroglyphidae). Egyptian Journal of Agric. Research. 82(3) : 1121 - 1126.

10. Wafa, A. K., M. A. Zaher, H. A. El-kifl and M. A. Hegazy. 1966. Survey on stored grains and seed mites (Acarina). Bull. Soc. Ent. Egypt, $50: 225-232$. 
تأثير أنواع مختلفة من الغذاء علي بيولوجية وخصوبة وجداول الحياة لحلم

$$
\text { الحبوب المخزونة }
$$

Gohieria fusca (Oud.) (Acari: Astigmata : Lapidophoridae)

$$
\begin{aligned}
& \text { حسن علي طه1 ، هناء إبراهيم محمود2 مصطقي إبراهيم حسن2 }
\end{aligned}
$$

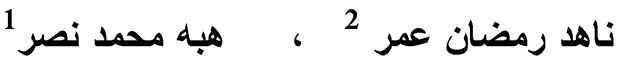

$$
\begin{aligned}
& \text { ا ـ معرد بحوث وقابة النباتات - مركز البحوث الزراعية - الدقي - الجبزة } \\
& \text { r r r كلبة العلوم جامعة الأزهر - مدينة نصر - القاهرة }
\end{aligned}
$$

أجريت دراسات بيولوجية لحلم الحبوب المخزونة Gohieria fusca تحت ظروف معملية عند

درجة حرارة 25ْم ورطوبة نسبية 65 \% لدر اسة تأثير ثلاثة أنواع من الغذاء هي : الخميرة الجافة المحبية وجريش القمح وجريش الذرة علي تطور وخصوبة وجداول الحياة .حيث أوضحت النتائج أن

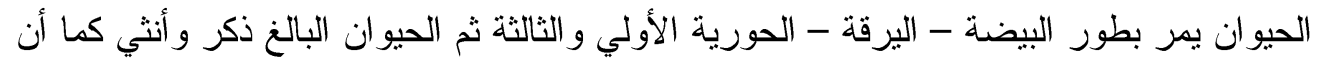

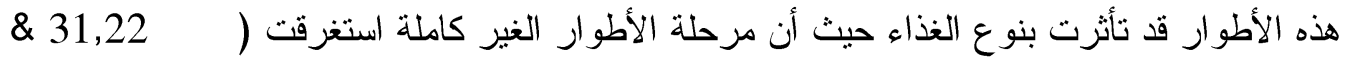

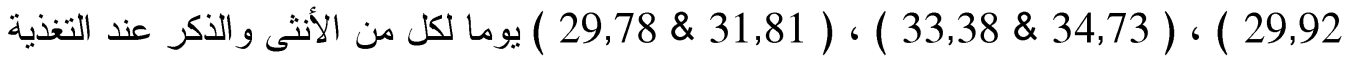
غلي أنو اع الغذاء المذكورة علي الترتيب كما أن مرحلة وضع البيض للأنثى استغرقت 26,8،

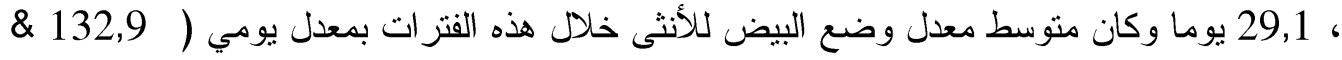

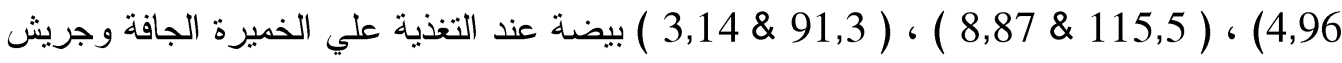

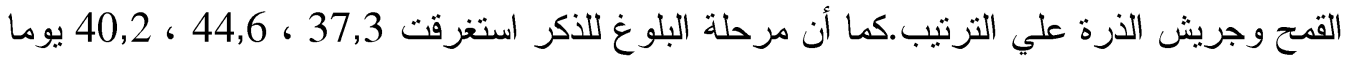

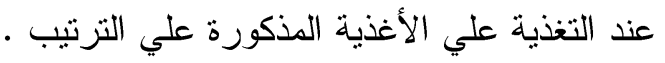

